\title{
Developing a STEM-based students' worksheet building material in elementary school Bandar Lampung City
}

\author{
Roni Agus Saputra *, Herpratiwi Herpratiwi, Caswita Caswita \\ Department of Primary Education, Graduate School of Universitas Lampung. \\ Jalan Prof. Sumantri Brojonegoro No. 1 Bandar Lampung, Indonesia \\ * Corresponding Author. E-mail: ronyagus486@gmail.com
}

\begin{abstract}
This study aims to produce students' worksheet-based STEM building material in elementary schools Bandar Lampung City. This type of research is research and development (Research and Development / R\&D). The main steps in this research and development are (1) information gathering and preliminary research; (2) planning; (3) product development; (4) limited testing; and (5) final product revision. The population in this study was the fifth-grade educators of SD Negeri Langkapura District Korwil III. The sampling technique used was the purposive sampling technique. The research sample was 3 (three) fifth-grade teachers of SDN 3 Langkapura, SDN 2 Langkapura, and SDN 1 Langkapura. Data collection techniques using observation and questionnaires. The data analysis technique in this study was using qualitative descriptive analysis techniques. Based on the results of research and discussion, it can be concluded that the development of STEM-based LKPD building material in elementary schools Bandar Lampung City is very feasible to use in learning. This is based on the results of the validation of material experts at $92.75 \%$, the results of the validation of design experts at $82.08 \%$, and the results of the test to the teacher at $93.04 \%$. This research is limited to the expert and practitioner test. It would be better if it was perfected in the effectiveness and attractiveness test.
\end{abstract}

Keywords: students' worksheet, Building Material, STEM

How to Cite: Saputra, R., Herpratiwi, H., \& Caswita, C. (2020). Developing a STEM-based students' worksheet building material in elementary school Bandar Lampung City. Jurnal Prima Edukasia, 8(2), 145-155. doi:https://doi.org/10.21831/jpe.v8i2.33478

\section{Introduction}

The $21^{\text {st }}$-century education requires students to manage the information; they learn through the activities of analyzing, assessing and creating. According to Bialik \& Charles (2015), the abilities that students must-have in the 21st century are Creativity, Critical Thinking, Communication, and Collaboration. Students must be able to use the information obtained to create something new, be able to make reasonable opinions, coordinate the knowledge gained, and collaborate with other students to build more optimal abilities. The ability to think creatively is one of the abilities students must possess to be able to solve various problems. According to Susanto (2016), creative thinking is more than critical thinking. If critical thinking can answer the problem or condition faced, while creative thinking is able to enrich the way of thinking with diverse alternatives. According to Irfana et al. (2019), the ability to think creatively is important for students to solve problems. This is because creative thinking is a basic ability that must be developed in schools.

Ability development is the goal of national education, one of which is the ability to think creatively. The main task of education is to create people who are able to do something new. According to Mahmudi (Wahyuni \& Kurniawan, 2018), the importance of the ability to think creatively is one of the abilities in the world of work. In this case, the low ability to think creatively can be shown from the results of answers about creative thinking abilities that researchers do when taking initial data. In the learning process, lecturers rarely or never lead to the ability to think creatively. The actual lecturer during the learning process has been good, but the lecturer paid less attention to student learning activities that lead to the process of creative thinking. Lecturers play an important role in the success of student learning, lecturers not only transfer knowledge, but lecturers also facilitate learning activities so that 
students can actively participate in learning. Creative learning is one of the national culture and characters. Creative learning is also important in improving the quality of learning, so creativity is competence in terms of learning processes and outcomes.

Mathematics is a subject containing full of life needs, such as a means of education. Mathematics as a means of education plays a role in human activities obtained from the thinking process, and it was not obtain from the experimental results (Damayanti \& Mawardi, 2018).

Mathematics is used to practice the ability to think and reason so that it can solve real-life problems. According to Sriwongchai et al. (2015), mathematics is the science of thinking and important thing to enhance thinking potency in the learning process. This because to learn concepts and solve the problem in mathematics well, critical and creative thinking skills is needed. The purpose of mathematics is not only to make students able to use mathematics theoretically but also to be applicable, to have logical and critical reasoning abilities in problem-solving.

The results of observations on August 20-25 2019 showed that learning applied more teachercentred approaches, namely the teacher became an information centre for students, so learning tends to be conventional. This learning pattern is more about the activeness of the teacher compared to the students. In addition, the teacher considers that learning in class is only to complete the material in the book. Students are seen as objects, not as subjects of learning, so students are less active in exploring knowledge.

Based on the results of the learning data, it can be seen that in SD Negeri 1 Langkapura out of 58 students, 27 students have not reached the minimum completeness criteria (KKM) with a percentage of the incompleteness of $46.56 \%$. At SD Negeri 2 Langkapura there were 38 students out of 64 students who had not yet reached the KKM with a percentage of the incompleteness of 59.38\%. While in SD Negeri 3 Langkapura, out of 55 students there were 25 students who had not yet reached the KKM with a percentage of the incompleteness of $45.46 \%$. So the average student who has not yet reached the KKM in mathematics from both elementary schools is $52.97 \%$. Based on Depdiknas (2006) This percentage of incompleteness is relatively low because ideally learning is said to be successful if at least $75 \%$ of students are able to reach the minimum completeness criteria.

The learning process is basically identical to the process of communication of knowledge from teacher to students or from students to other students. Quality learning can take place if the communication process runs smoothly, so teaching materials are needed as learning aids. One of the teaching materials that can support the learning process is the Student Worksheet (LKPD). In addition to playing a role as a guide for conducting activities, discussion guides and other scientific activities, LKPD also has an important role in the elaboration of the concept of knowledge.

LKPD is defined as printed teaching material in the form of sheets of paper containing material, summaries, and instructions for implementing the learning tasks that must be done by participants by referring to Basic Competence (KD) that must be achieved (Prastowo, 2015).

This is according to the LKPD definition according to Trianto (2010) is a student guide that is used to develop cognitive aspects as well as a guide to developing all aspects of learning in the form of guidelines for investigating or solving problems according to indicators of learning achievement that must be achieved. Choo et al. (2011) argue that LKPD is an instructional tool consisting of a series of questions and information designed to understand complex ideas, which guide students to carry out activities systematically.

According to Yasir et al. (2013) LKPD is a stimulus or teacher's guidance in learning that will be presented in writing so that in writing it needs to pay attention to the criteria of graphic media as visual media to attract the attention of students. The contents of LKPD messages must pay attention to the elements of graphic media writing, material hierarchy and question selection as an efficient and effective stimulus. Widjajanti (2014) explained that LKPD is one of the learning resources that can be developed by the teacher as a facilitator in learning activities. Aside from being a learning resource, LKPD is a learning media that can be used with other media.

Based on the results of interviews with fifth-grade elementary school teachers in Langkapura District, information was obtained that the use of LKPD mathematics has not been able to optimize the potential and creativity of students in mastering mathematical concepts. In addition, learning activities in LKPD are less varied, more dominated by activities working on problems oriented to logicalmathematical intelligence. In fact, in essence, each student has a different intelligence. 
In the elementary and high education of many countries, including Indonesia, what becomes the part of the conventional curriculum in Science and Mathematics whereas Technology and Engineering only occupy a very small portion in the curriculum. Mathematics and science can be the support for STEM education (Erviana \& Asmara, 2019).

Based on the results of previous studies indicate that LKPD can effectively improve students' creative thinking abilities. Irfana et al. (2019) conduct research that shows that LKPD developed includes science, technology, techniques, and mathematics. LKPD due diligence obtains very decent criteria, and readability test is in easy to understand criteria. STEM-based LKPD can improve the ability to think creatively with moderate improvement criteria. STEM-based LKPD is easy to understand and based on large group trials, STEM-based LKPD can improve the ability to think creatively, namely in the aspects of fluency, flexibility, elaboration, and authenticity marked by an increase in the value of pretest-posttest.

STEM is an interdisciplinary approach by integrating the four disciplines of science, technology, engineering and mathematics that are applied in a real-world context. According to Brown et al. (2011) STEM is a meta disciplinary at the school level where teachers of science, technology, engineering, and mathematics teach an integrated approach, and each discipline material is not divided but handled and treated as one dynamic entity. Integrating four disciplines through teaching and learning with a cohesive and active approach.

According to Pangesti et al. (2017), STEM is a term used to collectively refer to interdisciplinary teaching and approaches, namely science, technology, engineering, and mathematics. According to Sanders (2009), STEM is learning that combines two or more fields of science contained in STEM, and/ or between disciplines contained in STEM with one or two other school subjects. While opinions Kelley \& Knowles (2016) which states STEM is learning to teach STEM content from two or more STEM domains, bound by STEM practices in authentic contexts for the purpose of linking the subject in enhancing student learning. Other than that Lee et al. (2014) states that STEM is an engineering designbased learning that deliberately integrates between two or more fields of science contained in STEM and can expand its concepts to be integrated with other school subjects. This study aims to produce students' worksheet-based STEM building material in elementary schools Bandar Lampung City.

\section{Method}

This type of research is research and development (Research and Development / R\&D). The main steps in research and development refer to the research and development developed by Borg \& Gall (1983) that is (1) gathering information and preliminary research, (2) planning; (3) product development; (4) limited testing; and (5) revision of the final product. The population in this study was the fifth-grade educators of SD Negeri Langkapura District Korwil III. The sampling technique used was the purposive sampling technique. The research sample was 3 (three) fifth-grade teachers of SDN 3 Langkapura, SDN 2 Langkapura and SDN 1 Langkapura. Data collection techniques using observation and questionnaires. The data analysis technique in this study was using qualitative descriptive analysis techniques. The results of data analysis are used as a basis for revising the product being developed. The scoring guidelines can be seen in the Table 1 .

Table 1. Scoring Analysis Instruments Validation

\begin{tabular}{|c|c|c|}
\hline No. & Choice Answer & Score \\
\hline 1. & Very good & 5 \\
\hline 2. & Good & 4 \\
\hline 3. & Enough & 3 \\
\hline 4. & Less & 2 \\
\hline 5. & Very Less & 1 \\
\hline
\end{tabular}

Riduwan (2015)

The value given is one to five for a very good response, good, enough, less, and very less. The interval data can be analyzed by calculating the average answer based on the scoring of each answer from the response.

Percentage $=\frac{\text { Total Score-Score minimal }}{\text { Scors Maximal-Scoreminimal }} \times 100 \%$ 
Jurnal Prima Edukasia, 8 (2), 2020 - 148

Roni Agus Saputra, Herpratiwi Herpratiwi, Caswita Caswita

Furthermore, the percentage of eligibility obtained is then interpreted into the feasibility category based on the Table 2 .

Table 2. Eligibility Criteria

\begin{tabular}{cc}
\hline Percentage Score (\%) & Interpretation \\
\hline $0 \%-20 \%$ & Very not feasible \\
$21 \%-40 \%$ & Less Feasible \\
$41 \%-60 \%$ & Enough \\
$61 \%-80 \%$ & Feasible \\
$81 \%-100 \%$ & Very Feasible \\
\hline
\end{tabular}

Riduwan (2015)

\section{Results and Discussion}

Before the product development process, the researchers first conducted a preliminary study or needs analysis through the dissemination of a questionnaire regarding the ability to think creatively conducted on August 20-25, 2019 with the subject of 177 students of fifth-grade elementary schools in Langkapura who applied the 2013 curriculum. The questionnaire consisted of 20 statements which are arranged based on aspects of fluent thinking skills, flexible thinking, original thinking, and detailed thinking. Based on the results of the student's creative thinking questionnaire results obtained that $24.30 \%$ of students like to do experimental activities (including the detailing aspects), while $75.70 \%$ of students do not like to do experimental activities. This is because the experimental or experimental activities in finding mathematical concepts carried out are less interesting or too complex.

Furthermore, $56.20 \%$ of students do not like to give examples that are different from existing examples (including the original aspect of thinking). This is because students are accustomed to being confronted with mathematical problems only at the level of knowledge and understanding. As many as $43.50 \%$ of students readily see mistakes in solving problems (including the aspect of fluent thinking). This is because students are not given the opportunity to do an analysis of mathematical problems. Based on the results of the questionnaire, the three indicators above out of the ten indicators in the questionnaire of students' creative thinking abilities have calculation results below 50\%. Students' creative thinking abilities are low on aspects of fluent, original, and detailed thinking.

The results of the needs analysis on LKPD were also carried out with the subject of 6 elementary school fifth-grade teachers conducted by filling out a questionnaire on August 20-25, 2019. Based on the questionnaire there were $72 \%$ of teachers who did not make their own LKPD and 100\% LKPD compiled did not contain structure LKPD (title, study instructions, competencies to be achieved, supporting information, and assessment).

LKPD used has not been able to accommodate intelligence that has diverse students. In addition, the LKPD that was used also did not facilitate students' different learning styles. Based on the explanation, these conditions and potentials support the development of teaching materials in the form of STEM-based LKPD.

The initial product development process is based on an analysis of needs and a review of Core Competencies and Basic Competencies. The LKPD that was compiled was then validated by 3 people validating the material experts and three people validating the design experts. The results of the material expert validation can be seen in the Table 3 .

Table 3. Material Expert Validation Result

\begin{tabular}{|c|c|c|c|c|c|}
\hline No. Aspects of Assessments & Expert 1 & Expert 2 & Expert 3 & Score & Score Maximal \\
\hline 1. Suitability of LKPD Based STEM & 63 & 60 & 58 & 181 & 195 \\
\hline 2. Conformity of LKPD Content & 49 & 47 & 43 & 139 & 150 \\
\hline Score & & & & 320 & 345 \\
\hline Value & & & & & $92,75 \%$ \\
\hline
\end{tabular}

Based on Table 3, it can be seen the results of the validation of material experts on STEM-based LKPD products obtained a percentage of $92.75 \%$ with very feasible criteria. Furthermore, the results of the design expert validation can be seen in the Table 4. 
Jurnal Prima Edukasia, 8 (2), 2020 - 149

Roni Agus Saputra, Herpratiwi Herpratiwi, Caswita Caswita

Table 4. Design Expert Validation Result

\begin{tabular}{clcccc}
\hline No. & \multicolumn{1}{c}{ Aspects of Assessments } & Expert 1 & Expert 2 & Score & Score Maximal \\
\hline 1. & LKPD conformity with didactic requirements & 34 & 38 & 72 & 90 \\
2. & LKPD quality with construction requirements & 19 & 22 & 41 & 50 \\
3. LKPD compatibility with technical requirements & 40 & 44 & 84 & 100 \\
Score & & & 197 & 240 \\
Value & & & & 82,08 \\
\hline
\end{tabular}

Based on Table 4, it can be seen that the value of the results of the validation of design experts on STEM-based LKPD products obtained is a percentage of $82.08 \%$ with a very feasible category. Through the revision process, a product that is ready to be tested is limited to the teacher (practitioner). The results of the validation by the teacher can be seen in the Table 5 .

Table 5. Validation Result by Teachers

\begin{tabular}{clccccc}
\hline No. & \multicolumn{1}{c}{ Aspects of Assessments } & Teacher 1 & Teacher 2 & Teacher 3 & Score & $\begin{array}{c}\text { Score } \\
\text { Maximal }\end{array}$ \\
\hline 1. & Suitability of LKPD Based STEM & 61 & 55 & 58 & 174 & 195 \\
2. & Conformity of LKPD Content & 47 & 46 & 49 & 142 & 150 \\
3. & LKPD conformity with didactic requirements & 40 & 39 & 41 & 121 & 135 \\
4. & LKPD quality with construction requirements & 24 & 23 & 24 & 71 & 75 \\
5. LKPD compatibility with technical requirements & 49 & 49 & 50 & 148 & 150 \\
& Score & & & 656 & 705 \\
\hline
\end{tabular}

Based on Table 5, it can be seen that the assessment results of STEM-based LKPD products by teachers amounted to 93.04 with very feasible criteria.

STEM-based LKPD was developed by applying 4 STEM fields, that is: (1) Science was developed with students observing, conducting experiments related to volume and making cube nets and beams. According to Rustaman (2016), science has the skills of processes including observing, grouping, interpreting, predicting, asking questions, formulating hypotheses planning experiments, using tools/materials, applying concepts and communicating; (2) Technology was developed using mobile, internet and QR Barcode applications; (3) The technique was developed by arranging cubes and beams. According to Rustaman (2016), Engineering is the knowledge and skills to acquire and apply scientific knowledge, design and construct useful equipment, systems, materials and processes; (4) Mathematics is developed by calculating activities, finding the volume formula of cubes and beams, and solving problems about the volume of cubes and beams.

The STEM-based LKPD developed can be seen in the Figure 1-4. After revising the suggestions and input from material experts, design experts, and teachers, the final product in the form of STEMbased LKPD is obtained for the creative thinking ability of elementary school class V building materials that are very suitable for use in learning.

The development of STEM-based LKPD, products that have been developed has fulfilled the concepts of learning and learning. Based on the foundation of constructivism learning theory, learning is the result of students' construction as a result of their interaction with the environment. This is in accordance with the opinion Susanto (2016) that learning according to the theory of constructivism is that students must find out for themselves and transform complex information, check new information with old rules, and revise them if those rules no longer apply.

According to Vigotsky (Trianto, 2010), the learning process will occur if the child works or handles tasks that have not been learned, but those tasks are still within their reach which is commonly called the zone of proximal development, which is a level of development slightly above one's current area. Another important idea from Vigotsky is Scaffolding, which is to provide assistance to children during the early stages of development and reduce the assistance and provide opportunities for children to take over greater responsibility after the child can do it. The latest interpretation of Vigotsky's ideas is that students should be given the complex, difficult and realistic tasks that are then given sufficient assistance to complete the assignments (Tohir, 2015).

Therefore, the development of STEM-based LKPD is designed so that students can observe, experience themselves, and obtain information available in LKPD in the form of text, images, illustrations, or activity steps, thus encouraging students to construct knowledge with their own experience. 
Jurnal Prima Edukasia, 8 (2), 2020 - 150

Roni Agus Saputra, Herpratiwi Herpratiwi, Caswita Caswita

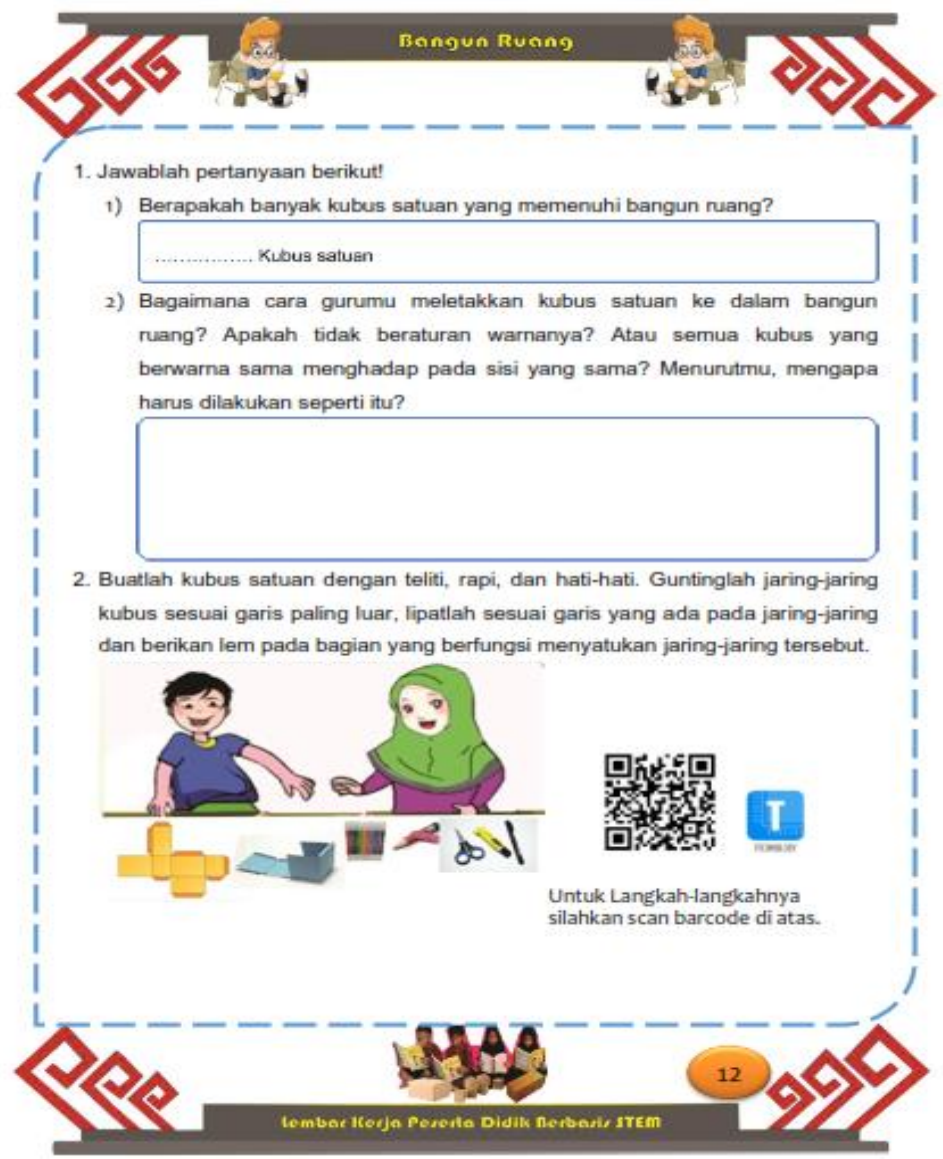

Figure 1. Science-Based Material Display

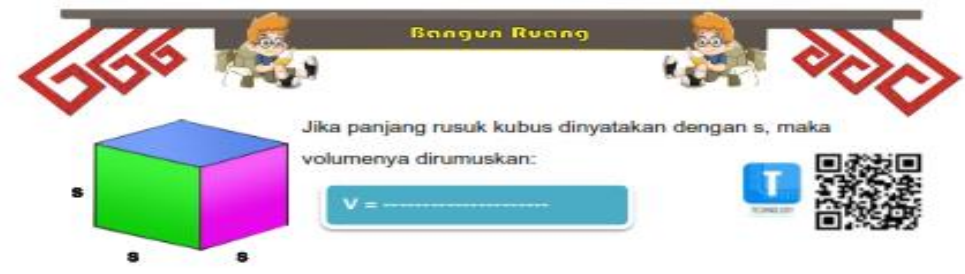

Jika sebuah balok berukuran panjang $=\mathrm{p}$. lebar $=1$, tinggi $=\mathrm{t}$, maka volumenya dapat dirumuskan:
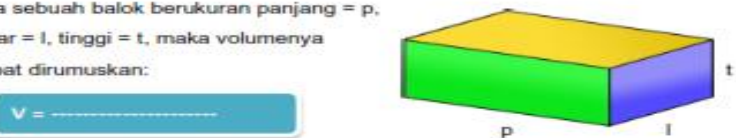

Ayo

Berlatih
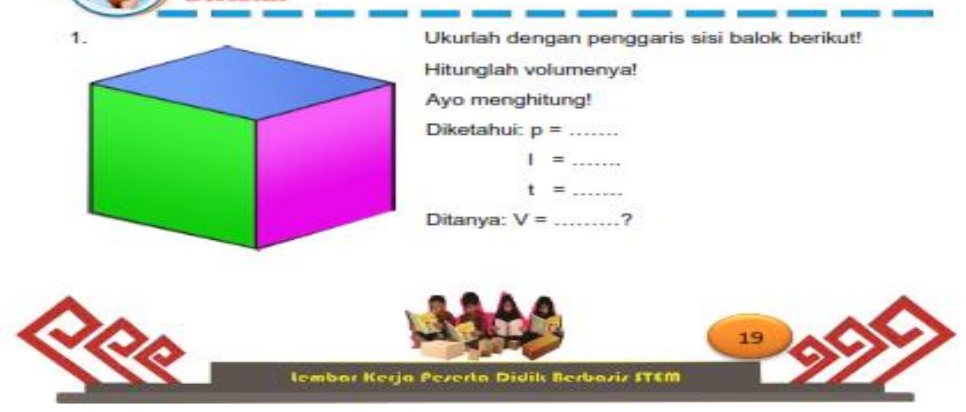

Figure 2. Technology-Based Material Display 
Jurnal Prima Edukasia, 8 (2), 2020 - 151

Roni Agus Saputra, Herpratiwi Herpratiwi, Caswita Caswita

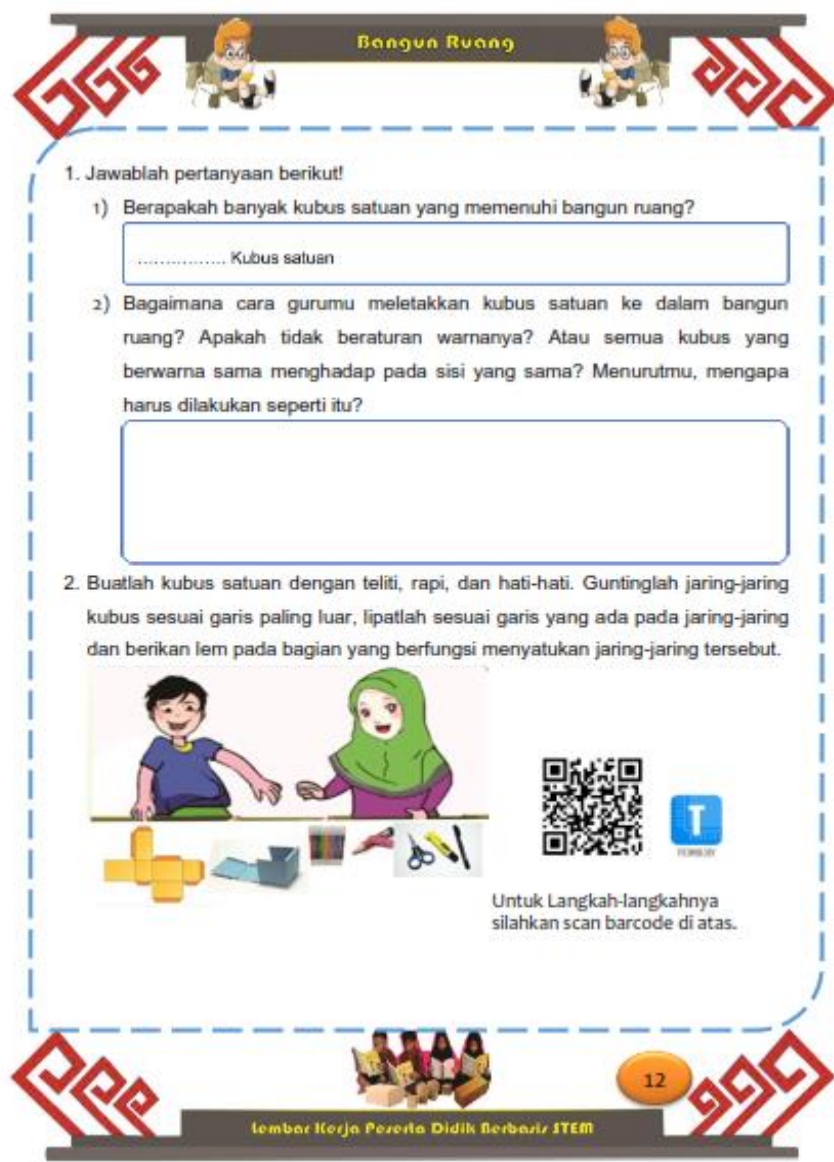

Figure 3. Engineering-Based Material Display

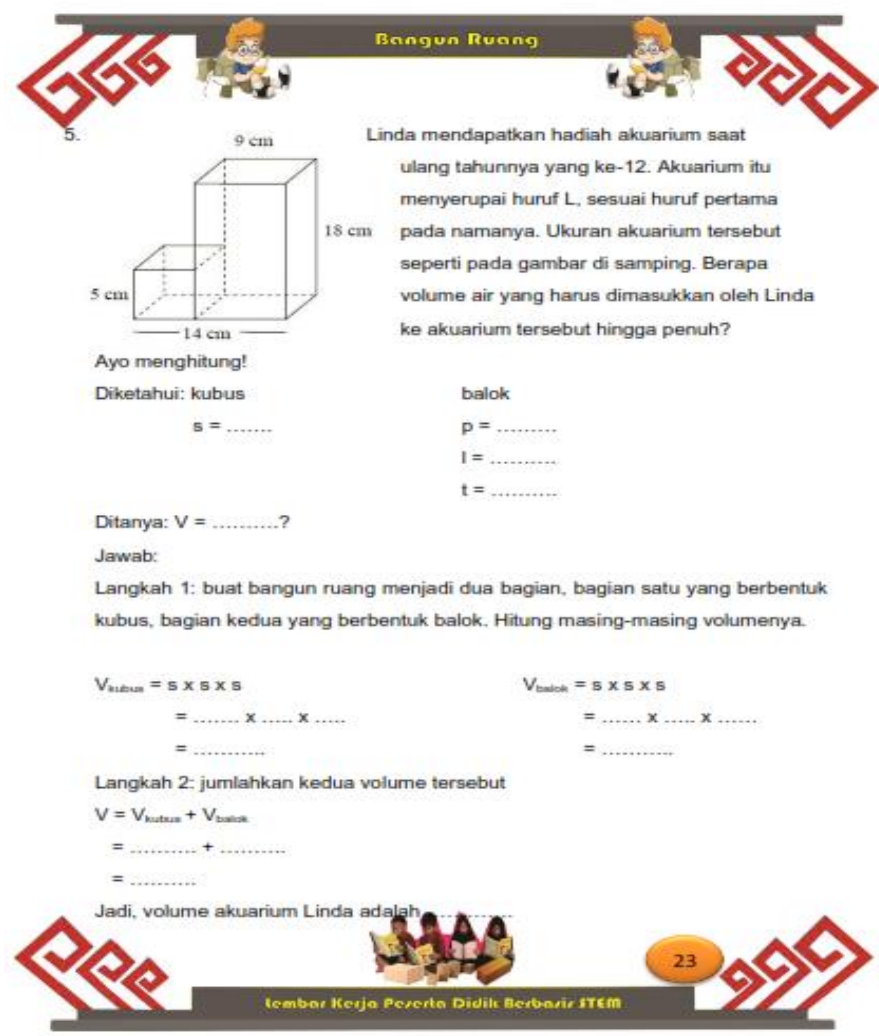

Figure 4. Mathematics-Based Material Display 
Jurnal Prima Edukasia, 8 (2), 2020 - 152

Roni Agus Saputra, Herpratiwi Herpratiwi, Caswita Caswita

STEM-based LKPD is considered very feasible based on material experts, design experts and practitioners. The results of this study are supported by research conducted by Utami et al. (2018) the results of the study show that the mathematics module with the STEM approach according to experts' assessment is very feasible. In addition, research conducted by Fatimah et al. (2019) showing LKS products for two lessons. The results of the two trials are used as a reference to carry out the product revision stage so as to produce the final product of the Student Worksheet on STEM-based outdoor learning.

The results of the development of LKPD products are as follows: First, Contains mathematics subject matter with basic competencies as following: (3.5) Explain and determine the volume of building space using a volume (such as a unit cube) and the relationship of a cube with cube root; (4.5) Resolving problems related to building volume using unit volumes (such as unit cubes) involving cube and cube roots. Second, LKPD was developed based on STEM, which contains Science, Technology, Engineering and Mathematics. Third, The LKPD that was developed contains indicators of creative thinking skills that are thinking smoothly, flexible thinking, original thinking, and the ability to detail.

In addition, the developed LKPD can support the learning process, help students to more easily understand the material and can train students to think creatively. This is in accordance with research journals Sulistyorini \& Abidin (2018) namely the development of LKPD is done to support student learning processes, help students understand the material, and train students to think critically so that they can solve problems that occur around them. In addition, according to Depdiknas (Sulistyorini \& Abidin, 2018), students' worksheet (LKPD) are sheets containing assignments that must be done by students. The activity sheet is usually in the form of instructions, steps for completing the task. The advantage of using LKPD is that it makes it easier for educators to carry out learning, for students it will be easier to learn independently and learn to understand and carry out a written assignment.

Mathematical creative thinking ability is the ability that includes four aspects, namely (a) fluency shows the ability of students to provide many ideas and solve problems with the right answers; (b) flexibility, namely the ability of students to solve problems in one way, then by using another method; (c) originality, namely the ability of students to solve problems in their own way; and (d) elaboration, namely the ability to solve problems by taking detailed steps (Suripah \& Sthepani, 2017).

\section{Current Thinking Ability}

Fluency according to Torrance (Armandita et al., 2017) is the ability to produce a number of ideas, the characteristics of fluency include: (1) Sparking lots of ideas, lots of answers, lots of problems solving, lots of questions smoothly; (2) Providing many ways or suggestions for doing various things; (3) Always think of more than one answer.

Flexible Thinking Ability

According to Prasetiyo (Armandita et al., 2017), flexible thinking is when someone is able to think of more than one idea in solving a problem.

Original Ability to Think

Torrance (Armandita et al., 2017) suggests that Originality, which has new ideas to solve problems. Original thinking is the ability to express ideas or solve problems in ways that no one else has ever thought of.

\section{Elaborative Thinking Ability}

The ability to elaborate according to Prasetyo (Armandita et al., 2017) is the ability to elaborate is one's ability to describe a simple thing to a broader definition.

Ghufron \& Rini (Mardhiyana \& Sejati, 2016) stated that the ability to think creatively has an important role in life because creativity is a reliable source of human resources to drive human progress in terms of search, development, and new discoveries in the field of science and technology as well as in all fields of human endeavour. The ability to think creatively is needed to develop oneself and solve problems encountered in daily life. Without the ability to think creatively, a person will not find answers to overcome his problems so that it is possible that there will never be progress in his life. The ability to think creatively can increase understanding and sharpen parts of the brain that are associated with pure cognitive. When the ability to think creatively develops, it will give birth to ideas, find interrelated relationships, create and do imagination, and have many perspectives on a matter. Students who have 
Jurnal Prima Edukasia, 8 (2), 2020 - 153

Roni Agus Saputra, Herpratiwi Herpratiwi, Caswita Caswita

high creative thinking skills tend to feel challenged and interested in solving various problems in learning.

The results of a study by Chittum et al. (2017) states that STEM has concepts and activities for motivating the students so that the students might learn more and also brings about positive impacts on the students' perception toward science. The learning pattern through the STEM approach has been proven to provide positive impacts in improving the students' achievements both in the academic and the non-academic domains from the interested improvement toward the wider level. It can bee is seen that there is an increase in interest, emphasis and interest in STEM-based schools and the need for understanding student outcomes (LaForce et al., 2016). The average STEM grades among the NA, SA, and French students were similar compared to the non-immigrant students, while the FSU students' average STEM grades were the lowest. Our findings suggest that both Segmented Assimilation Theory and Bourdieusian concepts of habitus and cultural capital should be considered to account for the educational STEM outcomes of immigrant children. These findings may inform educational policy and intervention programmes aimed at increasing high school STEM enrolment (Chachashvili-Bolotin et al., 2019).

What has been explained above has shown the connection or the importance of STEM-based LKPD as motivation to learn and enhance students' creative thinking abilities. With the help of LKPD students will try hard to solve a problem given by their teacher if they accept the challenges that exist in those problems. It is very important to formulate sentences on the problems that will be presented to students in interesting ways, related to their daily lives so that they are not too abstract, and can be solved by students, either with the help or without the help of the teacher. The learning process that conditions students to study groups and exchange ideas will make students accustomed to conducting investigations, usually starting with the screening of real problems that have been experienced. The weakness in this research is that learning has not been implemented using STEM-based LKPD so that it cannot know the effectiveness and attractiveness of STEM-based LKPD to improve students' creative thinking skills.

\section{Conclusion}

Based on the results of research and discussion, it can be concluded that the development of STEM-based LKPD building material in elementary schools Bandar Lampung City is very feasible to use in learning. This is based on the results of the validation of material experts at $92.75 \%$, the results of the validation of design experts at $82.08 \%$, and the results of the test to the teacher at $93.04 \%$.

The implications and suggestions for this research are (1) The next researcher can use this STEMbased LKPD to field testing to determine the effectiveness of LKPD; (2) This research is limited to the expert and practitioner test. It would be better if it was perfected in the effectiveness and attractiveness test; (3) Teachers can use STEM-based LKPD in learning to improve students' creative thinking skills.

\section{References}

Armandita, P., Wijayanto, E., Rofius, L., \& Susanti, A. (2017). Analisis kemampuan berpikir kreatif pembelajaran fisika di kelas XI MIA 3 SMA Negeri 11 Kota Jambi. Jurnal Penelitian Ilmu Pendidikan, 10(2), 129-135.

Bialik, M., \& Charles, F. (2015). Skills for the 21st Century: What Should Students Learn?

Borg, W. R., \& Gall, G. (1983). Educational research: An introduction, Fifth Edition. New York: Longman.

Brown, R., Brown, J., Reardon, K., \& Merrill, C. (2011). Understanding STEM: Current perceptions. International Journal Technology And Educator Association, 70(6), 5-9.

Chachashvili-Bolotin, S., Lissitsa, S., \& Milner-Bolotin, M. (2019). STEM outcomes of secondgeneration immigrant students with high-skilled parental backgrounds. International Journal of Science Education, 41(17), 2465-2483. https://doi.org/10.1080/09500693.2019.1686549

Chittum, J. R., Jones, B. D., Akalin, S., \& Schram, Á. B. (2017). The effects of an afterschool STEM program on students' motivation and engagement. International Journal of STEM Education, 4(1). https://doi.org/10.1186/s40594-017-0065-4 
Choo, S. S., Rotgans, J. I., Yew, E. H., \& Schmidt, H. G. (2011). Effect of worksheet scaffolds on student learning in problem-based learning. Journal Advances in Health Sciences Education, 16(4), 517-528. https://doi.org/10.1007/s10459-011-9288-1

Damayanti, R., \& Mawardi, M. (2018). Developing of MITRA learning model of problem solvingbased to solve mathematical problems in elementary school. Jurnal Prima Edukasia, 6(1), 1-10. https://doi.org/10.21831/jpe.v6i1.17238

Depdiknas. (2006). Lampiran 1 Permendiknas Nomor 22 Tahun 2006 tentang Standar Isi. Jakarta: Depdiknas.

Erviana, V. Y., \& Asmara, A. P. (2019). STEM-integrated encyclopaedia as the enrichment for elementary school students. Jurnal Prima Edukasia, 7(2), 114-127. https://doi.org/10.21831/jpe.v7i2.26594

Fatimah, S., Hamdu, G., \& Nugraha, A. (2019). Pengembangan lembar kerja siswa pada pembelajaran outdoor berbasis STEM di sekolah dasar. Pedadidaktika: Jurnal Ilmiah Mahasiswa Pendidikan Guru Sekolah Dasar, 6(1).

Irfana, S., Yulianti, D., \& Wiyanto, W. (2019). Pengembangan lembar kerja peserta didik berbasis science, technology, engineering, and mathematics untuk meningkatkan kemampuan berpikir kreatif peserta didik. UPEJ Unnes Physics Education Journal, 8(1), 83-89. https://doi.org/10.15294/upej.v8i1.29517

Kelley, \& Knowles. (2016). A conceptual framework for integrate STEM education. International Journal of STEM Education, 3(11).

LaForce, M., Noble, E., King, H., Century, J., Blackwell, C., Holt, S., Ibrahim, A., \& Loo, S. (2016). The eight essential elements of inclusive STEM high schools. International Journal of STEM Education, 3(1), 21. https://doi.org/10.1186/s40594-016-0054-z

Lee, H., Kwon, H., Park, K., \& Oh, H.-J. (2014). Development and application of integrative STEM (science, technology, engineering and mathematics) education model based on scientific inquiry. The Korean Association for Science Education Journal, 34(2), 63-78.

Mardhiyana, D., \& Sejati, E. O. W. (2016). Mengembangkan kemampuan berpikir kreatif dan rasa ingin tahu melalui model pembelajaran berbasis masalah. PRISMA: Prosiding Seminar Nasional Matematika, 1, 672-688.

Pangesti, K. I., Yulianti, D., \& Sugianto, S. (2017). Bahan ajar berbasis STEM (Science, technology, engineering, and mathematics) untuk meningkatkan penguasaan konsep siswa SMA. UPEJ Unnes Physics Education Journal, 6(3), 53-58. https://doi.org/10.15294/upej.v6i3.19270

Prastowo, A. (2015). Panduan kreatif membuat bahan ajar inovatif: menciptakan metode pembelajaran yang menarik dan menyenangkan. Yogyakarta: Diva Press.

Riduwan. (2015). Skala pengukuran variabel-variabel penelitian. Bandung:Alfabeta.

Rustaman, N. (2016). Pembelajaran sains masa depan berbasis STEM education. Makalah Seminar Nasional STKIP PGRI Sumatera Barat.

Sanders, M. (2009). STEM, STEM education, STEMmania. The Technology Teacher, 68(4), 20-27.

Sriwongchai, A., Jantharajit, N., \& Chookhampaeng, S. (2015). Developing the mathematics learning management model for improving creative thinking in Thailand. International Education Studies, 8(11), 77-87.

Sulistyorini, S., \& Abidin, Z. (2018). Pengembangan lembar kerja peserta didik (LKPD) tematik terpadu mengintegrasikan penguatan pendidikan karakter (PPK) dan literasi siswa SD Di Kota Semarang. Jurnal Kreatif, 8(2), 138-147.

Suripah, S., \& Sthepani, A. (2017). Kemampuan berpikir kreatif matematis mahasiswa dalam menyelesaikan akar pangkat persamaan kompleks berdasarkan tingkat kemampuan akademik. PYTHAGORAS: Jurnal Pendidikan Matematika, 12(2), 149-169. http://dx.doi.org/10.21831/pg.v12i2.16509

Susanto, A. (2016). Teori belajar \& pembelajaran di sekolah dasar. Jakarta: Kencana. 
Jurnal Prima Edukasia, 8 (2), 2020 - 155

Roni Agus Saputra, Herpratiwi Herpratiwi, Caswita Caswita

Tohir, A. (2015). Pengembangan bahan ajar modul kesetimbangan kimia berbasis multipel representasi di SMA Kota Bandar Lampung. Tesis: Program Pascasarjana Teknologi Pendidikan Fakultas Keguruan Dan Ilmu Pendidikan Universitas Lampung.

Trianto. (2010). Model pembelajaran terpadu. Jakarta: Bumi Aksara.

Utami, T. N., Jatmiko, A., \& Suherman, S. (2018). Pengembangan modul matematika dengan pendekatan science, technology, engineering, and mathematics (STEM) pada materi segiempat. Desimal: Jurnal Matematika, 1(2).

Wahyuni, A., \& Kurniawan, P. (2018). Hubungan kemampuan berpikir kreatif terhadap hasil belajar mahasiswa. Jurnal Matematika, 17(2). https://doi.org/10.29313/jmtm.v17i2.4114

Widjajanti, E. (2014). Kualitas lembar kerja siswa mata pelajaran kimia. Yogyakarta: Universitas Negeri Yogyakarta.

Yasir, M., Susantini, E., \& Isnawati. (2013). Pengembangan lembar kerja siswa (LKS) berbasis strategi belajar metakognitif untuk meningkatkan hasil belajar siswa pada materi pewarisan sifat manusia. Jurnal Bioedu, 2(1), 77-83. 